\title{
Fustification by Faith: a Patristic Doctrine
}

\author{
by D. H. WILLIAMS
}

\begin{abstract}
This essay challenges the criticism usually levelled at the early Fathers prior to Augustine for not articulating a view of justification by faith that corresponded with Pauline Christianity as reflected in the formulas of the sixteenth-century reformers. Not only is such a view anachronistic and tends to assume that there was (or is) a uniform definition of justification, but there is evidence that Latin theology before Augustine promulgated the tenets of unmerited grace and the necessity of righteousness that come only through justifying faith. In particular, the Matthew commentary of Hilary of Poitiers explicitly formulates a biblical theology of 'fides sola iustificat', and probably contributed to a revival of interest in the Pauline Epistles by the end of the fourth and early fifth centuries.
\end{abstract}

$\mathrm{I}$ $\mathrm{t}$ is still axiomatic for some Protestant writers that the principle of justification by faith was 'discovered' or 'rediscovered' by the Reformers. ${ }^{1}$ This often implies that the important principles expounded by Paul about the truth of salvation were overlooked or misunderstood by most of the early and medieval Church until Luther, meaning that not until the sixteenth century was Paul's teaching about the imputation of the righteousness of God to the sinner by faith properly interpreted and integrated into Christian history. Just as the notions of penance, tradition, sacraments etc. represented a series of corruptions from the simple and straightforward biblical message of the Church, so too the original apostolic intentions as expounded in Romans and Galatians became overlaid with an encrustation of alien teachings and practices sometime after the first century. The prevalent idea among those who pose these criticisms was that divine forgiveness was also grounded on the religious activity of the believer as a means of obtaining righteousness.

Such a caricature often consists of a dual assertion: first, that the older and broader narrative of soteriology in the historic Church had lost its way until it was found and elaborated upon by the Reformers, and second, that there is a

1 This is described in F. Hildebrandt, Christianity according to the Wesleys, Grand Rapids I996, I8, and Eberhard Jüngel, fustification: the heart of the Christian faith, trans. J. F. Cayzer, Edinburgh 2001, $70^{-}-3$. 
normative doctrinal formulation of justification by faith, founded upon the lines of Lutheran or Reformed expression, which declares that human beings are rightly accused of being entirely sinful before God, yet find acceptance before God who pronounces the sinner righteous solely because of Christ's merits. ${ }^{2}$ In response, it may be observed that while the doctrine of justification has been and continues to function as one of the central, if not the central, tenet of Protestantism, it is equally true that no one definition of justification holds sway among its major various confessing bodies. For example, the subscription of the Lutheran World Federation to the 'Joint Declaration on the Doctrine of Justification' with the Vatican ${ }^{3}$ does not mean that all Lutherans share a consensus on a particular statement of justification or agree with the wording of the Joint Declaration. ${ }^{4}$ For the purposes of this paper, therefore, justification will be defined simply as the moving of the human mind, will and heart toward God by the Holy Spirit through Christ, and the proposition that such a movement is by faith. By receiving the faith of the unrighteous, God reckons it to the believer as righteousness, resulting in the fruit of righteousness through the good works of the believer. ${ }^{5}$

Even if we were able to point to a uniform statement on justification, to view the sixteenth-century Reformation as the restoration of apostolic Christianity, especially Pauline Christianity, suggests that the Reformation is the bar by which all the rest of church history is judged. Patristic and medieval theologies amount to a series of incomplete or inadequate attempts at expressing the Gospel which is a problematic approach to historical theology. But most of all, the above caricature overlooks evidence on the initial development of the concept and language of justification by faith. Theological utilisation of the principle of justification by faith has its roots among patristic writers, as the Reformers themselves found when they sought precedents for their teaching. Without the Christological and soteriological

${ }^{2}$ God, who makes faith possible, is gracious and pronounces ungodly human beings righteous. Only faith can allow God to be God: Jüngel, Fustification, 236. From a Reformed perspective, a paper recently produced by Protestant scholars and activists holds that the 'doctrine of imputation (reckoning or counting) both our sins to Christ and of his righteousness to us ... is essential to the biblical Gospel' (article I2): 'The Gospel of Jesus Christ: an evangelical celebration', Christianity Today, I4 June I999, 51-6.

${ }^{3}$ The joint declaration was issued under the authority of the Lutheran World Federation and the Pontifical Council for Promoting Christian Unity: Gemeinsame Erklärung zur Rechtfertigungslehre, Frankfurt-am-Main I999-Grand Rapids 2000.

4 See Carl Braaten, Fustification: the article by which the Church stands or falls, Minneapolis I990, IO-I5. The same problem is noted by Anthony Lane as it pertains to Evangelicalism: fustification by faith in Catholic-Protestant dialogue: an evangelical assessment, Edinburgh 2002, 9.

${ }^{5}$ I am drawing from the wording of article 5 of the Regensburg Colloquy (I54I), a formula on justification which was agreed upon by Roman Catholic, Reformed and Lutheran representatives, but which was abandoned after the colloquy broke down on other theological points. 
doctrinal formations of the patristic age, the sixteenth-century formulation of justifying faith could never have been produced.

While it is not a novel observation that the salvific concept of justification was recognised among patristic writers, it is problematical to find scholarly studies that address this issue, and most of these (not unjustly) concern themselves with Augustine's landmark contributions. There is no question that the 'later' Augustine brings the Pauline concerns with justification by faith into the mainstream of Christian doctrine, concomitantly with the notions of grace and election, and permanently puts his stamp on the theological development of the west. ${ }^{6}$ Yet the status of the teaching of justification prior to Augustine seems to be largely ignored by doctrinal historians. Besides examining the writings of his monastic contemporary, Pelagius, for clues about what caused the subsequent controversy, Augustine's indebtedness to his predecessors lacks sufficient scholarly treatment. Perhaps this vacuum is due to the difficulties in locating exact theological antecedents to Augustine's mature theology, difficulties compounded by the fact that the development of a doctrine of justification was not a priority for early Christian thinkers. This, in turn, has fuelled the conclusion that the early Church showed an overall lack of interest in Pauline theology and its implications until Augustine. While standard reference works on 'Justification' acknowledge the utility of Origen's commentary on Romans, a fairly representative statement is 'The only patristic author who seems to appreciate the distinctively Pauline teaching was Augustine. ${ }^{77}$ More detrimental than silence are disparaging estimations given by some to the pre-Augustine era. One is reminded of T.F. Torrance's verdict against Clement and the 'Apostolic Fathers', charging them with directly contradicting Paul and promoting a theology of 'works'. 8 The otherwise impressive historical survey of justification by faith by Alister McGrath dismisses anything that pre-Augustinian writers had to say on the subject, on the grounds that patristic Christianity suffered from an acute case of dependency on Greek philosophy rather than on the Bible. Such a criticism is part of the longstanding legacy of unease about the patristic era on the part of Protestant

${ }^{6}$ In general, Augustine's writings do not present a uniform picture about sin, grace and election, just as they do not offer a uniform view about any major doctrine. A comparison of Augustine's On free will, bks i-ii, with On the grace of Christ and original sin and other later works will demonstrate clear differences in his perspective about the relation between human ability and God's omnipotence.

7 The encyclopedia of early Christianity, gen. ed. E. Ferguson, New York I993, 2nd edn, s.v. 'Justification'; cf. the Encyclopedia of the early Church, Oxford I992, on the same term. No writers earlier than Augustine and Pelagius are mentioned as having relevance to the patristic development of soteriology, which leaves the reader to assume that nothing of importance was written on the subject during the first four centuries of the Church except, of course, the Pauline letters.

8 T. F. Torrance, The doctrine of grace in the apostolic Fathers, Edinburgh I948, $44 \mathrm{f}$. 
scholars. ${ }^{9}$ Basing his opinion on the outmoded view that post-apostolic Christianity was corrupted by the vagaries of Hellenism, McGrath concludes that in terms of a theological understanding of justification, 'early theologians of the western church ... approached their text [the Latin Bible] and their subject with a set of presuppositions which owed more to the Latin language and culture than to Christianity itself' ${ }^{10}$ It is no wonder, then, that Latin theologians before Augustine all sound like 'Pelagians'.11

In like manner, McGrath claims that Greek writers maintained a positive estimation of the human capacity for the exercise of free will, with which they associated the necessity of obedience and of achieving purity. The vocabulary and philosophical understanding of self-determination or human free will became the predominant view of the early Church. Far from recognising the limitations of man's free will, patristic thinkers proclaimed the complete freedom of the will. The localisation of the origin of sin was to be found in the misuse of the human will, ultimately leaving humanity with freedom of choice. ${ }^{12}$ By the end of the fourth century, Greek Fathers had likewise 'formulated a teaching on human free will based on philosophical rather than biblical foundations' ${ }^{13}$ And contrary to biblical teaching - which McGrath usually equates with Pauline theology-a view of 'worksrighteousness' prevailed in the period before Augustine. While McGrath admits that a foretaste of a doctrine of grace may be discerned in the early centuries, it is questionable whether the optimistic patristic estimation of the

${ }^{9}$ I.e. The theology that Origen taught in his Pauline commentaries is said to have been a hybrid of Paul and Plato resulting in the disappearance of a Christian doctrine of salvation and justification by faith: Walter Völker, 'Paulus bei Origenes', Theologische Studien und Kritiken ccii (1930), 258-79. See also E. Aleith, Das Paulusverständnis in der alten Kirche, Berlin 1937, who declares that the early Fathers failed to understand Paul's theology of justification because they did not place it at the centre of Pauline teaching.

10 Alister McGrath, Iustitia dei: a history of the Christian doctrine of justification, Cambridge I986, i. I5. Tertullian is said to have "shackled the theology of the western church to a theology of "works" and "merit"'. The problem begins with the translation of the Greek verb meromai, to receive one's share (based on another's estimation) by the Latin mereri (meritum), which altered the meaning of the former to that which is deserved or merited. In other words, the Greek emphasis refers to something outside the person in question, whereas the Latin refers to the qualities of the person in question, or rather the inherent worthiness of the individual. This created a fundamental alteration in the concepts of righteousness and justification, which attributed the righteousness of the person to the person himself rather than to a righteousness placed upon him from the outside.

Another distortion of the pristine Christian message, according to McGrath, came with the introduction of the non-biblical, secular Stoic concept of autexousia (taking responsibility for one's action; self-determination), which by the late second century was translated by the early Fathers as 'free-will' ('liberum arbitrium').

11 McGrath, Iustitia dei, i. 22.

12 As McGrath rightly notes, the polemics against Gnosticism and astral determinism had no small role in the playing out of the patristic insistence that sinful humanity nevertheless possessed human free will.

${ }^{13}$ McGrath, Iustitia dei, i. I9. 
capacity of fallen humanity 'can be regarded as truly Christian in this respect'. ${ }^{14}$

McGrath's description of early Christianity's problem with 'hellenisation' does not carry the same pietistic disdain of doctrine and orthodoxy as manifested by Adolf von Harnack, writing a half-century earlier. Yet it does attribute to the early Church an inner conflict within its intellectual negotiation between the Bible and philosophy, and between genuine Christian development and corruptions of it, especially as it affected soteriology. ${ }^{15}$ While some adaptation to the intellectual milieu was incumbent upon Christianity in order to present the Gospel to an alien culture, 'it is equally evident that such an adaptation may result in both a compromise and distortion of the characteristic and distinctive elements of the gospel ${ }^{\prime}{ }^{16}$ As it concerned the Pauline teaching of justification, there were 'distortions' which were introduced into the body of Christian tradition at an early stage.

But was the pre-Augustine patristic era so ignorant of the content of Paul's Epistles and so misguided as to their teaching? The rest of this essay will demonstrate briefly some specific examples of how the concept of justification was formulated in patristic writers well before the 'Pelagian controversy', that is, before 4II-I2. In particular Hilary of Poitiers's commentary on Matthew's Gospel reveals a striking awareness of this concept that has been almost completely ignored by modern scholarship.

Early church historians generally agree that theological emphases during the patristic period centred on ontological issues of the divine nature as it relates to a Trinitarian understanding of God and on the being and work of Christ as God incarnate. This is not to imply that there was such a uniformity of interest on the part of early Christian writers that one cannot find ample material on concepts of soteriology, the sacraments etc. There is frequent mention of the way in which the Law and prophets should be related to the Christian kerygma. As the early Church sought to define its identity in light of its Jewish roots and its relation to the Hebrew Bible, debate about the relation between Law and Gospel often impinged on the Christian idea of salvation.

14 Ibid.i. 20.

15 This is very similar to the theological paradigm which late nineteenth- and early twentieth-century scholarship used in the interpretation of the 'Arian controversies', which was itself based on the language of heresiology from the late patristic era. Characteristically, Arius' views were inspired by pagan philosophy which was superimposed upon scriptural testimonies, which meant that his theology of the Father and Son was not Christian. Athanasius, on the other hand, was informed by a truly biblical exegesis of Christ. See the introduction in M. R. Barnes and D. H. Williams (eds), Arianism after Arius: essays on the development of the fourth century Trinitarian conflicts, Edinburgh i993.

16 McGrath, Iustitia dei, i.I8. 
Against perceived imbalances among certain Jewish Christians, Polycarp's letter to the Smyrnaeans cites Ephesians ii. 8 - the first known citation of this passage - 'by grace you are saved not from works ... and so leave the empty talk and the deceit of many'. Polycarp may see in his own mid secondcentury situation a continuation of the struggles Paul waged against a Jewishlike legalism of works (i.3-ii. I), which he too wished to correct as inconsistent with the Gospel. The authentic letters of Ignatius and the Epistle of Barnabas clearly show there were severe conflicts between Christians and Jewish Christians over the relevance of the Law in the interpretation of the Christian message. The extremes of, on the one hand, judaizing Christians, who mandated a literal reading of the Mosaic covenant, and Marcion's complete rejection of the historical relevance of the Old Testament for Christianity, were already coming into expression by this time. But concern with these extremes was not the sole occasion for echoing Pauline theology. The late first-century letter known as I Clement contains quotations almost solely from the Hebrew Bible, yet exhibits a predominance of Pauline themes such as frequent reference to believers as God's elect, the use of doxologies throughout the course of the letter ${ }^{17}$ and contentions that God's faithful are made just by faith.

Also among the so-called 'Apostolic Fathers' corpus, the anonymous Epistle to Diognetus, written about the same time as or slightly later than Polycarp's letter, manifests theological sensitivity to the relation between the sinfulness and powerlessness of the human condition before God, and our need for the righteousness of God. In this text there are no direct quotations from the Pauline Epistles. Nevertheless, the writer speaks plainly of an inability to enter the kingdom of God according to our own worthiness or goodness. Our hope lies only in the saving power of God which was demonstrated by the ransoming of His righteous Son for our unrighteousness: 'In whom was it possible for us, the lawless and ungodly, to be justified, except in the Son of God alone? O sweet exchange, $\mathrm{O}$ the incomprehensible work of God, $\mathrm{O}$ the unexpected blessings, that the sinfulness of many should be hidden in one righteous man, while the righteousness of one should justify many sinners! 18

In none of these instances can one say that we are witnessing the initial expounding of a doctrine of justification by faith. It is accurate to say only that they are occasional moments of direct reflection on Pauline theology during the first three centuries, and when these instances do occur, there is often recognition that the righteous are made righteous by faith. Of course, one can also find very un-Pauline perspectives, such as the injunction in the Didache (I9.Io) that one must work to ransom's one's sins (though the writer

17 See I Clement ii.5; xxxii.4; lviii.3. I am indebted to Fr Denis Farkasfalvy of the University of Dallas for his observation about the division of I Clement according to the placement of the doxologies.

18 Epistola ad Diognetum ix.4-5. 
is not propounding a soteriology). The Shepherd of Hermas, likewise, presents the Christian faith in terms that demonstrate an almost complete ignorance of God's gracious act of redemption in Christ. ${ }^{19}$ Even in these cases, however, there is no need to think that patristic writers had become so philosophically and culturally intoxicated that they were no longer vitally concerned with establishing clarity for the way of salvation based upon Scripture and the Church's tradition.

With the prodigious production of biblical commentaries in Alexandria in the middle of the third century, we catch a glimpse of what early Greek Christianity thought of the Epistles of Romans and Ephesians. Clement of Alexandria is said to have made brief comments on Paul's Epistles, ${ }^{20}$ but other than a few fragments this work is not extant. Origen's efforts represent the first known large-scale commentary among Latin or Greek authors on select Pauline letters. These texts demonstrate clearly that he insisted on the absolute necessity of faith and good works; the two are organically linked in such a way that Origen rarely articulates the one without the other. In his commentary on Romans, Origen presents faith as a truly personal relationship with Christ grounded solely on receiving faith, reflected in the experiences of the thief on the cross or the woman who was a sinner (Luke vii). At the same time, he safeguards the idea from any approach that interprets God's justifying faith as an excuse for failing to pursue a personal righteousness. Origen's chief concern was for those who used faith as a means of escaping moral culpability because their actions were predetermined by God or the stars, or because their nature had preordained them to a course of action. ${ }^{21}$ Belief which does not yield the fruit of good works is therefore in vain. The efficacy of saving faith, which Paul expressed in unqualified and all-embracing terms, appears in Origen, though in brief and restricted ways. Like most second- and third-century writers, Origen relates Paul's declaration of justifying faith to the forgiveness of past sins. ${ }^{22}$ God grants the ability to avoid future sins, but the Christian who has faith is culpable for his actions and must undergo a judgement on the basis of his works. It was inconceivable to Origen that such faith could be separated from the believer's progress in virtue. Faith and works go together like the two testaments: you must have both for Christian truth and perfection.

Thanks to the influence of Origen's writings in the later fourth and early fifth century, Greek writers, most notably John Chrysostom, similarly

19 Shepherd of Hermas, Vision ii.2: 'If this sin is recorded against me, how can I be saved? Or how will I propitiate God for my conscious sins?'; cf. Vision iii.ro; Mandate iii.28.

20 The work is called Hypotyposes by Eusebius of Caesarea: Historia ecclesiastica ii. I4. I.

21 Origen, Commentary on Romans ii. 4, 7.

22 Ibid.ii.7, 7. See Maurice Wiles, The divine Apostle: the interpretation of St Paul's Epistles in the early Church, Cambridge ig67, in if. 
espouse the corresponding efforts of divine grace and human response. ${ }^{23}$ The translation of many of Origen's works by Rufinus, Jerome and unknown others meant that the commentary on Romans was available to Latin readers and would have its most enduring effect in the west. Pelagius certainly knew and used it. ${ }^{24}$ And a convincing case has been made by the late C. P. Bammel to the effect that Augustine was indebted to Origen's commentary as the African bishops struggled with the Pauline emphasis on justification by faith and the necessity of good works after baptism. ${ }^{25}$ When Augustine writes, 'Laudo superaedificationem operis, sed video fidei fundamentum; laudo fructum boni operis, sed in fide agnosco radicem, ${ }^{26}$ he was relying on Origen's exposition of Romans, positing faith as the foundation upon which works are built and faith as the root which brings forth the fruit of good works.

Turning to Latin literature, it was not until the mid-fourth century, with the first known commentaries on Galatians, Ephesians and Titus by Marius Victorinus, ${ }^{27}$ that western theology began to make a more thorough inquiry into the implications of Pauline theology. One of the few scholarly examinations of the early Latin patristic use of Paul's thought has focused on these commentaries, and the results of this work make it clear that Victorinus taught salvation by grace through

${ }^{23}$ Perhaps the most succinct and precise passage that demonstrates the unity of human and divine wills is found in Chrysostom's Homily on the Gospel of Matthew lxxxii:

From this we learn an important doctrine, that people's good will is not enough if they are not in receipt of grace from on high, and correlatively that we profit nothing from grace from on high if good will is lacking. Both these truths Judas and Peter demonstrate: though one enjoyed much assistance, it did him no good because he lacked good will and contributed nothing of his own, whereas the latter, though full of good will, came to grief because he received no assistance. Virtue, you see, is woven from these two things. Hence I urge you not to leave it all up to God and fall asleep, nor in a flurry of zeal to think you achieve the whole thing by your own efforts. In fact, God does not want us to be lethargic - hence his not doing everything himself; nor to be presumptuous - hence his not leaving it all up to us; instead, he removed the harmful element in each option, and left to us the beneficial part. This is why he allowed even the chief apostle to fall, to render him less presumptuous and to prompt him to stronger love in future; Scripture says, 'The person to whom more is forgiven will love more'; cf. Luke vii.47.

24 A. J. Smith, 'The Latin sources of the Commentary on the Epistle of St Paul to the Romans', JTS xix (I918), I62-230; xx (1919), 55-65, г27-77.

${ }^{25}$ C. P. Bammel, 'Justification by faith in Augustine and Origen', this Journal xlvii (I996), $223_{26}^{-35}$.

${ }_{26}$ Augustine, Enarrationes in Psalmos iii.I7-I9. Until the 'Pelagian controversy', Augustine seems to have understood justification simply as without antecedent merits so that works before faith are useless.

27 For a critical edition and Italian translation see Marii Victorini: Commentarii in epistolas Pauli ad Ephesios, ad Galatos, ad Philippenses (Mario Vittorino: Commentari alle epistole di Paoli agli Efesini, ai Galati, ai Filippesi), ed. F. Gori, Turin I981. 
faith. ${ }^{28}$ We are not saved by our own merits, as if by the works of the law, but only by the grace of God: 'it is by faith alone that brings justification and sanctification' ${ }^{29}$ Rather rigidly attached to the wording of the Pauline text, Victorinus does not seek to investigate any further what justification as saving faith means for the Christian. We are freed from our sins by belief in Christ, but good works are expected to follow this forgiveness in a reciprocal fashion. We will be made righteous if faith is present, yet this faith will only be full faith if we act righteously. ${ }^{30}$

While Victorinus may have produced the first exegetical treatments of the Pauline Epistles, he was not the first to integrate the teaching of justification by faith into Christian theology. Virtually ignored among the treatments of early Christian thought is Hilary of Poitiers, a bishop and theologian whose contributions were seminal for the establishment of Trinitarian and Christological theology in the west before Augustine. Just as noteworthy were Hilary's scriptural exegetical labours, the earliest of these being his commentary on the Gospel of Matthew. This is a remarkable work in several ways, not least in that it is the first Latin biblical commentary to be preserved almost completely intact, ${ }^{31}$ and it is therefore of enormous value in reconstructing the exegetical and literary history of the western Church during the early 35 os. It offers a close look at Latin theology and exegesis before the Nicene Creed was considered the sole standard of orthodoxy ${ }^{32}$ Of particular relevance for our task here is the way in which the Pauline theme of justification by faith is positioned so prominently in Hilary' commentary some sixty years before Augustine.

Some twenty varied occurrences of the phrase, 'fides iustificat' (or 'fidei iustificatio') are to be found through the thirty-three-chapter work, expressing a concept germane to an understanding of the Gospel. It would seem that Hilary's interest involves much more than mere restatements of Pauline passages. That this author, writing a commentary on Matthew, should use Paul's language and concepts so frequently demonstrates that they are for him an indispensable factor for achieving an adequate understanding of how the sinner is made righteous.

${ }^{28}$ Robert Eno, 'Some patristic views on the relationship of faith and works in justification', Recherches augustiniennes xix (1984), 3-27. A shorter version of the same title is found in H. G. Anderson and others (eds), Fustification by faith: Lutherans and Catholics in dialogue, vii, Minneapolis I985, II I-30. 29 Victorinus, Commentarii ad Galatos ii.15-16.

${ }^{30}$ Eno, 'Some patristic views', i I4.

31 The original preface appears to have been lost (ii.I opens with 'ut quia diximus' though not in reference to anything said in ch. i), and the commentary ends with Matthew xxviii.I3, which is seven verses too short, and has no epilogue. Jean Doignon produced a new critical edition of the commentary in 1978 (SG ccliv, cclviii; pts I and II of the commentary). The first English translation of the work will appear in the near future in the Fathers of the Church series.

${ }^{32}$ See D. H. Williams, 'Defining orthodoxy in Hilary of Poitiers' Commentarium in Matthaeum', Fournal of Early Christian Studies ix (200I), I5I-7I. 
Fundamental to Hilary's description of the message of salvation is that the bonds of the Law, chained by its acknowledgement of sin, are loosed 'through an understanding of evangelical freedom'. ${ }^{33}$ Even though the same Law proclaimed Christ and his coming (cf. Luke xxiv.44-7) and had been established for the realisation of the need for faith (xvi.3), it became a liability when used as an end in itself, effectively preventing many Jews from appropriating Christ. The problem with trying to keep the Law is that one is not able to follow it and accept God's justifying grace. By not having faith, those who follow the Law lose what they have of the Law (xiii.2). ${ }^{34}$ Very often Hilary contrasts the legalism of unbelief and unworthiness with salvific faith. The former is a salvation of works, which leads to unbelief and even animosity toward faith, whereas those who have no achievement to their credit are prepared to realise that 'salvation is entirely by faith' (xi.Io). 'The work of our salvation is not in sacrifice but in mercy and, with cessation of the Law, we are saved by the goodness of God' (xii.5). So, too, the withered fig-tree in Matthew xxi is said to be a figure of the chief priests and Pharisees who 'have not been justified by faith, nor have they returned through repentance to salvation' (xxi.I4). The pagans, on the other hand, are justified by the arrival of salvation and it is 'for their sakes [the Lord] is come' (xxi.2). Not all is lost for the Jews, however, since just as some believed through the Apostles, so it is through Elijah that others will believe and be justified by faith (xxvi.5) $;^{35}$ thus, one part of Israel is embraced by the same faith of good works, whereas the other is left behind in the fruitless works of the Law.

Hilary has to be careful not to reduce Old Testament functionally to a position of virtual worthlessness, as Christian extremists in previous centuries were known to have done in their zeal to show the triumph of grace through Christ. The Apostle Paul's description in Romans xi of Israel's place in God's redemptive scheme is an implicit backdrop to the bishop's thinking. Even though the basis of the Gentiles' salvation is derived from Israel's transgression of disobedience, Israel continues in its election and will ultimately be saved (Rom. xi.25-32).

33 'et quod intra eam peccatorum fraude sit vinctum per intelligentiam libertatis evangelicae absolvatur': Hilary of Poitiers, In Matthaeum xi.2 (Doignon edn, i.254). This is more than a passing theme for Hilary: cf. xi.8 ('freedom of life in Christ'); xix. Io ('freedom of the Gospel'); and xxx.I ('liberty of the Gospel').

34 'It disturbed the scribes that sin was forgiven by a man (for they considered that Jesus Christ was only a man) and that sin was forgiven by Him whereas the Law was not able to absolve it, since faith alone justifies' ('Movet scribas remissum ab homine peccatum [hominem enim tantum in Iesu Christo contuebantur] et remissum ab eo quod lex laxare non poterat; fides enim sola iustificat'): ibid. viii. 6 ( Doignon edn, i.200).

35 'aloquin iustificatio ex fide nulla est, si fides ipsa fiat ambigua': ibid. v. 6 (Doignon edn, i. 54,6$)$. 
In the commentary's discussion about the parable of the talents (Matt. xxv.I4-30), true believers in the Old Testament are not made righteous by their devotion to the Law. By their obedience to the divine precepts of the Law, however, they do demonstrate a faith that corresponds to the life-giving precepts of the Gospel. Indeed, Hilary points out that the servant who had gained five talents besides the five talents he was given had performed obedience according to the ten precepts of the five books of Moses. But he was able to do so because he had acted in faith upon adherence to the Law, through the grace of the Gospel's justification. The servant is told, therefore, to enter the joy of the Lord; that is, he is received in the honour of Christ's glory (xxvii.7).

The model of obedience for the Jews was Abraham, who was worthy as one justified by faith (ii.3), so that 'through faith believers are the descendants of Abraham' - a distinct echo of Pauline theology. Of course, if justice had come from the law, forgiveness though grace would not have been necessary (ix.2). Only an abuse of the Law, as seen in the conduct of the Pharisees, brings about an opposition to the necessity of faith before God ${ }^{36}$ Before or after the coming of Christ the means of righteousness has always had the same source: that which comes only 'through grace of the gospel's justification' (xxvii.7). This fact was vividly demonstrated, just as Origen had acknowledged, by the thief on the cross ('at Jesus' right hand'), who was saved only according to justification of faith. Our salvation lies only in the goodness of God, a goodness which Hilary calls 'the perfect gift' (xii. 5 ; xiii.2): we are 'made alive through the grace of the Spirit whose gift comes... through faith' (xv.ro).

The parable of the workers in the vineyard presents itself for Hilary as an excellent case for illustrating that salvation is completely God's gift (Matt. xx.I-I6). Despite the fact that some workers were hired at the eleventh hour of the day, they received the same wages as those who were hired in the morning. The remuneration for those hired last demonstrates that it was not based on the merit of their labour. Rather, 'God has freely granted his grace to all through justification by faith.' This was the only means, Hilary says, by which the pagans (Gentiles) were saved. They were the last ones 'hired' by the owner of the vineyard, yet first to receive remuneration:

When it began to get late, the workers of the evening hour were the first to obtain the payment as determined by a whole day's work. Payment is certainly not derived from a gift because it was owed for work rendered, but God has freely granted his

${ }^{36}$ Cf. " "Woe to you scribes and Pharisees, you hypocrites who travel over sea and land." By their wandering over sea and land, the Lord indicates that they represent all parts of the earth who will belittle the gospel of Christ and with the yoke of the Law, they will compel others to oppose justification by faith' ('Maris et terrae peragrinatione significat in totis orbis finibus eos esse Christi evangelio obtrectaturos et legis iugo contra iustificationem fidem aliquos subdituros'): ibid. xxiv.5 (Doignon edn, ii. I68). 
grace to everyone by the justification of faith ... Thus [God] bestows the gift of grace by faith on those who believe, either first or last. ${ }^{37}$

The theological significance of justification by faith, as Hilary frequently reminds us, is no minor matter for a proper interpretation of all Scripture. Echoing Rom. iii.24, he declares that the truth of justification constitutes the message of the very 'gospel [which] had to be preached throughout the whole world'. He is quite conscious that divine revelation came by stages through the epochs of human history. A prominent part of God's purposes is God's offer of justification to the pagans or Gentiles, which is essential to the ordo of salvation history.

It is historically important to note that Hilary is the first Christian theologian explicitly to have formulated what Paul left implicit by referring to God's work of grace in the phrase, 'fides sola iustificat': 'Because faith alone justifies... publicans and prostitutes will be first in the kingdom of heaven' (xxi.I5). ${ }^{38}$ And yet it is not his intention to elaborate on an overall soteriological scheme, but to explain how the pagans have come to share legitimately in the covenant originally given to Israel.

While Hilary does not articulate a concept of original sin, through his reading of Paul he anticipates the mature views of Augustine. He declares that all humanity is implicated in Adam's downfall, that no person is without sin and no one by his own merits can free himself from that sin. Because of the sin of one, the sentence of condemnation is passed on all. ${ }^{39}$ Not only does he proclaim this doctrine, he comes as close as any early writer before Augustine to formulating the term 'original sin:

When therefore, we are renewed in the laver of baptism through the power of the Word, we are separated from the sin and source of our origin (ab originis nostrae peccatis atque auctoribus), and when we have endured a sort of excision from the sword of God, we differ from the dispositions of our father and mother [e.g., Adam and Eve]. And we, casting off the old man with his sins and unbelief (Colossians iii.9-1o) and renewed in soul and body by the Spirit, ought to despise the customary ways of our natural and former deeds (Col. iii.5-8). And because the body itself has been

37 'Et cum sero esse coepisset, donum constitutae in totius diei labore mercedis, primi operarii horae vesperis consequunter. gratuitam gratiam Deus omnibus ex fide iustificatione donavit ... ideo donum gratiae per fidem credentibus primis et novissimis largiatur': ibid. xx.7 (Doignon edn, ii.ıı).

38 'quia fides sola iustificat. Atque ideo publicani et meretrices in regno caelorum erunt priores' (Doignon edn, ii.I40).

39 'Ovis una homo intelligendus est et sub homine uno universitas sentienda est. Sed in unius Adae errore omne hominum genus aberravit': ibid. xviii.6 (Doignon edn, ii.8o); 'in filiis hominum ob id quia iam in uno Adam omne humani generis exordium constitisset': De trinitate iv.2 I (Hilaire de Poitiers: la Trinité, ed. P. Smulders, SG ccccxlviii, Paris 2000, ii. 54). 
mortified (Rom. viii.I3) through faith, it rises to the nature of the soul, which comes from the breath of God. ${ }^{40}$

He makes similar claims when commenting on Jesus' healing of the paralytic by forgiving him his sins: 'In the one man Adam, the sins imputed to the whole of humankind are forgiven '41 and on Psalm li.7 (Psalm i.7): 'under the origin of sin and under the law of sin he knows that he was born ${ }^{42}$ Only by regeneration will the free gift of God avail the human condition and, moreover, the grace by which the believer is maintained is God's spontaneous and unconditional free gift. Despite the fact that sin entered the world through one man, the gift of grace of the one Man, Jesus Christ, brings forgiveness. ${ }^{43}$

While Hilary's emphasis on the bestowal of God's righteousness upon a helpless race before the demands of the Law represents a more pronounced application of this side of Paul's thought than is perceptible in previous writers, it was not a theology de novo. Hilary was an original thinker, but one finds various themes from Hippolytus, Tertullian, Cyprian and Novatian and other westerners in his theology. ${ }^{44}$ Like other patristic writers, Hilary does not view human nature as completely helpless and moribund in the exercise of its moral will. God has authorised humanity to exercise that will for the sake of the good or evil and freely respond to the call of the Gospel.

There is the strong possibility that Hilary's commentary sparked or fuelled the revival of Pauline studies in the west during the last decades of the fourth century. Hilary's writings appear to have been copied and made widely available soon after his death $(c .367)^{45}$ and within a decade a common interest in Pauline texts and themes is evident among such widely divergent thinkers as Augustine, the Donatist Tyconius, Pelagius and Priscillian of Barcelona (reputed, albeit wrongly, a neo-Manichaean). This revival within

${ }^{40}$ In Matthaeum x.24. See E. W. Watson's comments, Nicene and Post-Nicene Fathers ix, pp. lxxxvi-lxxxvii.

${ }^{41}$ In Matthaeum viii.5; drawing on Romans v.12-2I for an explanation of Matt. ix. 2.

${ }^{42}$ Hilary of Poitiers, Tractatus in Psalmos i i 8.xxii.6.

${ }^{43}$ Hilary speaks once or twice about God's election, his argument, however, is not derived from a particular theory of divine predestination, but is a means of explaining God's way of dealing with the results of the Adamic fall.

44 This is a subject that Doignon has examined with great care: Hilaire de Poitiers avant l'exil, Paris I971, I69-225.

45 C. Kannengiesser, 'L'Héritage d'Hilaire de Poitiers', Recherches de science religieuse lvi (1968), 435-56; P. Smulders, 'Remarks on the manuscript tradition of the De trinitate of Saint Hilary of Poitiers', Texte und Untersuchungen lxxviii (196r), I29-38. Already by 430, the same year that Augustine died, a dossier or florilegium of Hilarian texts was circulating in the west and was being used by Arnobius the Younger, Leo of Rome, John Cassian and Celestine of Rome. See J. Doignon, 'Une Compilation de textes d'Hilaire de Poitiers presentée par le Pape Celestin I à un cóncile romain en 430', in Oikoumene: studi paleocristiani pubblicati in onore del concilio ecumenico Vaticano II, University of Catania i964, 477-97. 
the Latin Church has been hailed by Peter Brown as the generation of St Paul. ${ }^{46}$ Correspondingly, the second half of the fourth century also saw a rapid increase in the number of biblical commentaries published in the west, especially on Pauline letters. Commentaries became the all-important medium of transmitting theology that had previously been conveyed mainly by polemical treatises. Given the fact that Hilary's Trinitarian and Christological theology is so often cited by later writers, it stands to reason that his Matthew commentary would have exerted no less influence on subsequent Latin literature. ${ }^{47}$

Augustine's experiences and theology shows that he was a beneficiary of the renewed interest in Paul's letters, and that he stood in a succession of writers who benefited from the repercussions of Pauline theology shaping Latin hermeneutics. Besides the works of Marius Victorinus, those of another Italian writer, whose identity is unknown but has been dubbed since the editions of Erasmus as 'Ambrosiaster', suggest that the renewed interest in Pauline theology was already underway by the late 370 os. $^{48}$ Ambrosiaster's complete set of commentaries on all the Pauline Epistles represented that exegetical enthusiasm (as did Jerome's commentaries on Galatians, Ephesians and Philemon). On the one hand, Ambrosiaster represents the simpler perspective about faith and works found in Victorinus. Grace and forgiveness are gifts from God and not a reward for our good works. By faith alone one is freely forgiven of all sins and the believer is no longer burdened by the Law for meriting good works. Our works, however, are demonstrative of our faith and will determine whether we are ultimately justified. While faith does justify, faith is also the first good work that begins the process of justification and sanctification. On the other hand, Ambrosiaster appropriated Paul's Epistle to the Romans in a manner closer to that of Hilary. The germ of the doctrine of original sin is present; we are said to be all born under sin so that all have sinned as in Adam and are held under the dominion of $\sin .{ }^{49}$ In order to be redeemed, therefore, we are justified or set free from sin's power. Ambrosiaster says several times that this justification is an act of the Holy Spirit and that is what the believer receives in order to become a child of God. ${ }^{50}$

${ }^{46}$ Peter Brown, Augustine: a biography, Berkeley, CA I967, I5I.

${ }^{47}$ P. Smulders, 'Hilarius van Poitiers als Exegeet van Mattheüs' ('Hilary of Poitiers as an exegete of St. Matthew'), Bijdragen xliv (1983), 75 .

${ }^{48}$ The complete text is in CSEL lxxxi, pts I-3. In the 370s 'Ambrosiaster' emphasised the effect of original sin inherited by all humanity. We all thus sinned en masse in Adam and stand guilty before God: A. Pollastri, Ambrosiaster: commento alla lettera ai romani, Aquileia I996, I06-I5.

${ }^{49}$ Pollastri, Ambrosiaster, I08-9. The carrier of our inherited sin is the body, not the soul.

50 'Non autem scriptum est tantum propter illum solum, quia reputatum est illi, sed etiam propter nos, quibus reputabitur credentibus in eum, qui suscitavit Iesum Christum dominum nostrum ex mortuis, qui traditus est propter peccata nostra et resurrexit propter iustificationem nostrum': Ambrosiaster, Ad Romanos iv.23-5, CSEL lxxi.I49; 'spiritus enim dei 
Augustine and Pelagius independently produced biblical commentaries early on in their respective careers and well before the 'Pelagian controversy', each of them drawing on Latin and Greek predecessors. Around the time he became a presbyter at Hippo (394), Augustine wrote his only direct commentaries on Paul: one on Galatians, another on select passages from Romans, and the start of what would have been a massive commentary on Romans, though he never got beyond the first seven verses. But by no means was Augustine's exegetical work on Paul limited to biblical commentaries as To Simplicianus and On eighty-three different questions bear witness.

Pelagius, writing on the same scale as Ambrosiaster, and perhaps in opposition to his conclusions, published brief commentaries on all Paul's letters. ${ }^{51}$ During the late fourth century Augustine and Pelagius were quite similar in the way that they juxtaposed faith and good works. Indeed, Augustine had treated Pelagius with deference and with an irenic spirit before $4 \mathrm{II}-{ }^{-12}$. Of course Pelagius had not denied the central place of grace, declaring that we are saved by grace and not by works. However, the exigencies of his situation convinced him to commit himself to theological positions that went beyond the earlier Latin tradition. He controversially affirmed the perseverance of natural grace which meant that one had the innate resources not to sin. On his part, Augustine evolved in ways that separated him from his earlier perspective and from earlier writers by stressing both the total inability of the natural man, and God's sovereignty and affirmation of the absolute priority of grace. The human will, unaided by saving grace, will never want to seek any good except its own. Yet, God's purposes of redemption cannot be thwarted or dictated by human choices - an axiom that Luther will later espouse as central to his theology. The sinner is completely justified by faith because nothing on the part of the sinner can promote or stall God's salvific action on his behalf. Put in this way, one may say that Augustine was not propounding a doctrine of soteriology as much as he was defending a theology proper to the opening of the creed: 'I believe in God the Father Almighty'.

It should go without saying that the theologians of the early Church do not articulate soteriology in the same way as did the Augsburg Confession or Martin Chemnitz, nor should we expect them to. As A. N. S. Lane observes, the pre-Reformation Church may have understood the doctrine of justifying faith, but not in the terms of sixteenth-century Protestantism. ${ }^{52}$ It is entirely

nescit peccare; ad iustificationem enim datur, ut adiutorio suo iustificet ... signum enim iustificationis hic est in homine, ut per id quod inhabitat in eo iustificatus appareat esse filius dei', ibid. 8, го (267).

51 A. Souter, Texts and Studies ix (1926), 227; Patrologiae cursus completus, series latina, supplementum, i. In Io-374; T. De Bruyn, Pelagius's commentary on St Paul's Epistle to the Romans, Oxford I993.

${ }^{52}$ Lane, Justification by faith, 146. 
anachronistic to weigh the merits of the earlier solely in light of the later. We find, rather, that early Christian thought calls us to reconsider the divine richness out of which Christian perspectives on salvation in general and justification in particular emerged. The way in which the magisterial Reformers focused on Augustine's anti-Pelagian works for their reading of the great African bishop may rightly be questioned. It is still debatable whether Augustine's linkage of predestination, irresistible grace and justifying faith, forged in the heat of polemical exchange, represents the mainstream or the necessary outcome of Augustine's theology. In any case, Luther drew heavily from Augustine's later theology and in so doing narrowed the theological vision of the broader patristic contours of justification by faith. ${ }^{53}$ But that is for another study.

It is clear enough that the majority of patristic witnesses to the meaning of Scripture did not use Pauline theology as the template by which all other scriptural testimonies must be evaluated, nor did they share Luther's canonwithin-a-canon approach. ${ }^{54}$ Instead, ancient notions of God's grace and human ability were derived from a governing perspective of the Bible as a unified and interrelated composition. ${ }^{55}$ Basic to patristic hermeneutical assumptions was the sense that any one text of Scripture had to be interpreted in light of all the rest of Scripture, both Old and New Testaments. Scripture shares an inner coherence and design because of its divine origins, which means that the act of interpretation is in reality a task of unveiling and clarifying the pattern of truths already present in the structure. A theology gained from one text can and should inform the construal of others. It was

${ }^{53}$ Despite Luther's recorded quip in his Table talk that Augustine did not rightly understand justification by faith, he cites or alludes to Augustine and other patristic writers countless times throughout his biblical and theological works. Melanchthon and the signatories of the Augsburg Confession likewise defended their view of justification by faith as that which was reflected in the writings of the early Fathers. The same indebtedness is expressed by Calvin in his Institutes and commentaries. It should be noted that references to patristic precedents were generated by rhetorical or polemical motives. At the same time, we cannot completely throw out the expressed intent of Lutheran and Reformed theologians who repeatedly sought to demonstrate that justification by faith was not a new teaching and that one could find warrant for it in the works of post-New Testament exegesis. Those writings of the patristic age with which the early Reformers were familiar convinced them that their project had to be about restoring the catholic faith of the first five centuries.

${ }^{54}$ Karl Schelkle makes this point in his well-known study of the early Fathers' exegesis of Romans. In contrast to the magisterial side of the Protestant Reformation, which conceived of the New Testament message as organised around Paul and justification, patristic theologians emphasised the doctrine of God and Christology, sacramental theology, the typological aspects of the Law and Judaism and the relationship between grace (new covenant) and works (old covenant): Paulus, Lehrer der Väter: die altekirchliche Auslegung von Römer I-II, Düsseldorf I958, 418-39.

55 Peter Gorday, Principles of patristic exegesis: Romans $9^{-I I}$ in Origen, Fohn Chrysostom and Augustine, Toronto-New York I983, 36-8. 
automatic, therefore, for patristic writers ${ }^{56}$ to find Pauline perspectives in their reading of the Gospel and vice-versa. They would not have shared the antagonistic exegesis of the early twentieth-century New Testament scholars who pitted Matthew's Jewish colouring of the kerygma against the teaching of the Apostle to the Gentiles. ${ }^{57}$ For Hilary, as we have seen, the Gospel of Matthew itself taught and illustrated the teaching of justification by faith. $\mathrm{He}$ was not blind to the differences between Pauline and Matthean texts, but he did read them as parts of the same divine continuum and thus sharing similar purposes. Likewise, the recent assertion ${ }^{58}$ that the witness of James and Matthew is in no way compatible with the Pauline doctrine of justification would have been regarded as biblically debilitating.

This holistic approach to the Bible is also related to a basic conviction of the early Church that the work of justification is integral to the whole work of the Trinity, from whom flows the life of God experienced by the believer through faith and in good works leading toward virtue. Any theory of salvation is only as potent as the theory about the God who provides it. For this reason Karl Barth refused to accept the doctrine of justification by faith as, in Luther's words, 'the teacher, chief, lord, rule and judge over all other doctrines ${ }^{59}$ of the evangelical message. While the necessity and importance of the particular function of the article of justification cannot be denied, it is just that: a particular aspect of the Christian message of reconciliation. It is not the theological truth upon which everything else is based. Barth rightly contended that this doctrine has not always been the Word of the Gospel and that it would be 'an act of narrowing and unjust exclusiveness' in the Church's theological history were we to treat it as such. ${ }^{60}$ Rather, the being and activity of Jesus Christ for us is the centre of Christian theology and provides cohesiveness for drawing all its doctrinal aspects together. ${ }^{61}$ The doctrine of justification is to convey the being and life of Jesus Christ for us, to us and with us. We would expect Barth to say this, of course, but his point about the priority of God's revelation of Himself is well taken. The basis and culmination of the doctrine of justification is in the Church's confession of the life of God imparted to us in Christ. This seems to be the perspective articulated in the Joint Declaration on the Doctrine of Justification, signed by Roman Catholic and Lutheran representatives, which states in paragraph 15 that

56 See, for example, Origen, Commentarius in Fohn i.5.10; i.4.23; ii.9.21, and Commentarius in Matthaeum x. 2, 5, 9; xi. 3 .

${ }^{57}$ G. H. Dodd offered a credible refutation of the alleged anti-Pauline bias in Matthew:'Matthew and Paul', Expository Times lviii (1946-7), 293-8. I am thankful to Professor Paul Burns of the University of British Columbia for alerting me to this article.

${ }^{58}$ Jüngel, fustification, I9.

59 'Articulus iustificationis est magister et princeps, dominus, rector et iudex super omnia genera doctrinarum': Luthers Werke, Weimar i883, xxxix. 205.2

60 Karl Barth, Church dogmatics, Edinburgh I936, iv/ı, 523.

${ }^{61}$ Ibid. iv/I, 527-8. 
In faith we together hold the conviction that justification is the work of the triune God. The Father sent his Son into the world to save sinners. The foundation and presupposition of justification is the incarnation, death and resurrection of Christ. Justification thus means that Christ himself is our righteousness, in which we share through the Holy Spirit in accord with the will of the Father.

In sum, theological scepticism about the priority of saving faith and unmerited grace in the pre-Augustine period has been overstated. Most early church writers would have whole-heartedly agreed with Paul's words, 'Therefore, if anyone is in Christ, he is a new creature; the old things are passed away; behold, new things have come. Now all these things are from God who reconciled us to himself through Christ' (2 Corinthians v.I7-I8). There can be no question that a strong theological position of solus Christus underlay the early Church's soteriology. Christ alone was 'true God of true God' and was able to fulfil the divine plan of recreating the fallen creation. It was all but universally accepted that the work of salvation is completely God's work on our behalf and that without God's initiative toward us in Christ, Adam's race has no hope. Whatever good the human will might achieve, it is not enough for humanity's redemption. We cannot be saved by our good deeds, though no less true was the Apostle's admonition that we should 'work out our salvation with fear and trembling' (Philippians ii.I2) or acknowledge that only for those who love God will all things work out for the good (Rom. viii.28).

While it is hazardous to generalise, we may say that the early Fathers maintained the free and unmerited character of God's grace toward fallen humanity, expressing it sometimes in the terms of justification by faith. However, they rarely linked the initiative of divine grace with election and predestination, nor did they usually make a necessary correlation between the reality of human sinfulness and the complete inability of the human will. Faith is a divine work of salvation 'in us' as well as 'for us' in the work of transformation and that the believer may behold God. ${ }^{62}$ There is not the kind of 'gap' between God's graciousness and our obedience which Augustine opened for polemical purposes and that shaped sixteenth-century soteriology. Furthermore, faith for the ancients was something definable. One was justified according to the lex fidei; the catholic faith, which the Christian, once made righteous, must subsequently follow. Those who do not receive this fides in love are not justified because they seek rather to observe the works of the Law.

And thus a correction of the sixteenth-century corrective may be necessary as contemporary Protestantism seeks to understand itself in light of the whole inheritance of the historic exegesis of the faith. We must see that the

62 Salvation was the beginning of the Christian life that led to the purification of the soul, in accordance with the principles implied in Titus ii. II-I4, and culminated in divine theosis. 
post-Augustinian legacy in the west ${ }^{63}$ valuable as it was, also obscured earlier voices that also spoke for orthodoxy and the Church, voices that can still contribute to discussions about the theological roots of justification by faith. Instead of mitigating the contributions of the pre-Augustinian legacy, we may rather observe the ways in which it may serve to balance the Protestant insistence that the doctrine of justification is expressed only as the imputation of an alien or external righteousness to the sinner. It can be reasonably advocated that the ancients' less complicated emphasis on righteousness received through the incarnate Christ, rather than by adherence to the Law, stands closer to Paul's message than those who would later reduce the testimony of the entire New Testament to a singular vision.

63 One must distinguish Augustine from the sort of 'Augustinian' legacy in which the former's teaching on grace, human will and predestination become systematised and centralised in subsequent appropriations of him. For the need for this distinction see Gerald Schlabach, 'Augustine and the Augustinians', in D. H. Williams (ed.), The Free Church and the Early Church, Grand Rapids 2002, 47. 